\title{
PENGARUH GAYA KEPEMIMPINAN DAN MOTIVASI KERJA TERHADAP KINERJA PEGAWAI
}

\author{
EFFECT OF LEADERSHIP STYLE AND WORK MOTIVATION TO EMPLOYEE \\ PERFORMANCE
}

Diterima: 23032018

Andhi Sukma Hanafi ${ }^{1}$, Chairil Almy ${ }^{2}$, M.Tirtana Siregar ${ }^{3}$

${ }^{1)}$ Universitas Syah Kuala, Jl. Tgk. Syech Abdul Rauf, Kopelma Darussalam, Syiah Kuala,

Kota Banda Aceh, 23111, Indonesia

${ }^{2)}$ Management and Science University, Malaysia

${ }^{3)}$ Politeknik APP Jakarta, Jl. Timbul No. 34 Jakarta

\section{email: 4ndh15ukma@gmail.com}

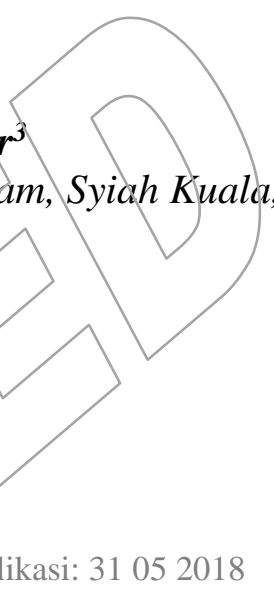

\section{Abstract}

Leadership style is a style used by a leader to lead the organization by using existing resources within the organization to achieve organizational gaals. Human vesources are one of the resources that exist within the organization that can be utilized leader for the achievement of organizational goals. Employees are human resources that can be utilized by a leader in achieving organizational goals. It is important for a leader to be able to use an appropriate leadership style with the organization, in an effort to improve employee work motivation, which affects the performance of employees who support the achievement of organizational goals. In this study will be discussed about the performance of employees who are influenced by the style of leadership and work motivation. The results showed that employee performance is influenced by the level of work motivation and leadership style. In addition, the appropriate styte of leader will affect the level of employee motivation, so it can significantly improve the performance of employees within an organization.

Keywords : leadership style, work motivation, employee performance

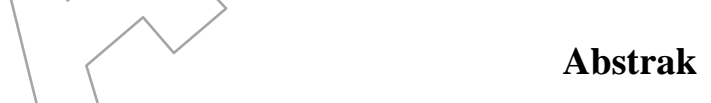

Gaya kepemimpinan merupakan gaya yang digunakan oleh seorang pemimpin untuk memimpin organisasi dengan menggunakan sumber daya yang ada dalam organisasi untuk mencapai tujuan organisasi. Sumber daya manusia merupakan salah satu sumber daya yang ada dalam organisasi yang dapat dimanfaatkan pemimpin untuk pencapaian tujuan organisasi. Pegawai merupakan sumber daya manusia yang dapat dimanfaatkan oleh seorang pemimpin dalam mencapai tujuan organisasi. Sangat penting bagi seorang pemimpin untuk dapat menggunakan gaya kepemimpinan yang sesuai dengan organisasi, dalam upayanya untuk meningkatkan motivasi kerja pegawai, yang berpengaruh terhadap kinerja pegawai yang mendukung pencapaian tujuan organisasi. Dalam penelitian ini akan dibahas mengenai kinerja pegawai yang dipengaruhi oleh gaya kepemimpinan dan motivasi kerja. Hasil penelitian menunjukkan bahwa kinerja pegawai dipengaruhi oleh tingkat motivasi kerja dan gaya kepemimpinan. Selain itu, gaya pemimpin yang sesuai akan berpengaruh terhadap tingkat motivasi kerja pegawai, sehingga secara signifikan dapat meningkatkan kinerja pegawai dalam suatu organisasi.

Kata kunci : gaya kepemimpinan, motivasi kerja, kinerja pegawai 


\section{PENDAHULUAN}

Kinerja suatu organisasi sangat ditentukan oleh kualitas sumber daya manusia yang ada didalamnya, mulai dari kemampuan menangkap permasalahan yang ada dalam organisasi, melakukan analisa permasalahan, dan mengantisipasi dampak yang akan terjadi dalam organisasi tersebut. Sehingga dapat dikatakan bahwa pegawai sebagai sumber daya manusia dalam suatu organisasi merupakan aset penting yang harus diperhatikan.

Kinerja pegawai merupakan hasil kerja secara kuantitas dan kualitas yang dicapai oleh seorang pegawai dalam melaksanakan tugasnya sesuai dengan tanggung jawab yang diberikan kepadanya dalam pencapaian tujuan organisasi. Kinerja pegawai dipengaruhi oleh tingkat motivasi kerja dari pegawai untuk menjalankan tugas dan fungsinya dalam pencapaian tujuan organisasi. Disinilah pemimpin mengambil peranan penting dalam menjalankan peran motivato bagi pegawai yang dipimpinnya. Suatu kepemimpinan sangat diperlukan suatu organisasi dengan harapan dengan kepemimpinan yang sesuai akan memudahkan berkomunikasi dan mengatur pegawai dalam menyelaraskan tujuan organisasi.

Dalam memimpin, seorang pemimpin memiliki gaya masing-masing yang dipengaruhi oleh karakter, pendidikan dan lingkungan. Gaya kepemimpinan merupakan gaya yang digunakan oelh seorang pemimpin untuk memimpin organisasi dengan menggunakan sumber daya yang ada dalam organisasi untuk mencapai tujuan organisasi. Sumber daya manusia merupakan salah satu sumber daya yang ada dalam organisasi yang dapat dimanfaatkan pemimpin untuk pencapaian tujuan organisasi. Pegawai merupakan sumber daya manusia yang dapat dimanfaatkan oleh seorang pemimpin dalam mencapai tujuan organisasi. Untuk itu, sangat penting bagi seorang pemimpin untuk dapat menggunakan gaya kepemimpinan yang sesuai dengan organisasi, dalam upayanya untuk meningkatkan motivasi kerja pegawai, yang berpengaruh terhadap kinerja pegawai yang mendukung pencapaian tujuan organisasi.

\section{LANDASAN TEORI}

\section{Pengertian Kinerja Pegawai}

Kinerja berasal dari kata job penformance atau actual performance yang berarti prestasi kerja atau prestasi sesungguhnya yang dicapai oleh seseorang. Performance atau kinerja merupakan hasil atau keluaran dari suatu proses (Nurlaila, 2010) ${ }^{[18]}$.

Kinerja merupakan prestasi kerja, yaitu perbandingan antara hasil kerja dengan standar yang ditetapkan (Dessler, 2007) ${ }^{[11]}$. Kinerja adalah hasil kerja baik secara kualitas maupun kuantitas yang dicapai oleh seseorang dalam melaksanakan tugas sesuai tanggung jawab yang diberikan (Mangkunegara, $2005)^{[16]}$. Kinerja adalah hasil atau tingkat keberhasilan seseorang secara keseluruhan selama periode tertentu dalam melaksanakan tugas dibandingkan dengan berbagai kemungkinan, seperti standar hasil kerja, target atau sasaran atau kriteria yang telah ditentukan terlebih dahulu telah disepakati bersama (Rivai, 2009) ${ }^{[20]}$.

Sedangkan Mathis dan Jackson (2006) ${ }^{[17]}$ menyatakan bahwa kinerja pada dasarnya adalah apa yang dilakukan atau tidak dilakukan pegawai. Manajemen kinerja adalah keseluruhan kegiatan yang dilakukan untuk meningkatkan kinerja perusahaan atau organisasi, termasuk kinerja masing-masing individu dan kelompok kerja di perusahaan tersebut. Kinerja merupakan hasil kerja dari tingkah laku (Amstrong, 1999) ${ }^{[9]}$. Pengertian kinerja ini mengaitkan antara hasil kerja dengan tingkah laku. Sebagai tingkah laku, kinerja merupakan aktivitas manusia yang diarahkan pada pelaksanaan tugas organisasi yang dibebankan kepadanya. 
Dari beberapa pengertian diatas maka dapat disimpulkan kinerja pegawai adalah hasil kerja secara kualitas dan kuantitas yang dicapai oleh seorang pegawai dalam melaksanakan fungsinya sesuai dengan tanggung jawab yang diberikan kepadanya.

Kinerja dipengaruhi oleh berbagai faktor, menurut Prawirosentono (1999) ${ }^{[19]}$ ada beberapa faktor yang berpengaruh terhadap kinerja, diantaranya:

a. Efektifitas dan efisiensi, bila suatu tujuan tertentu akhirnya bisa dicapai, kita boleh mengatakan bahwa kegiatan tersebut efektif tetapi apabila akibat-akibat yang tidak dicari kegiatan menilai yang penting dari hasil yang dicapai sehingga mengakibatkan kepuasan walaupun efektif dinamakan tidak efesien. Sebaliknya, bila akibat yang dicari-cari tidak penting atau remeh maka kegiatan tersebut efesien.

b. Otoritas (wewenang) adalah sifat dari suatu komunikasi atau perintah dalam suatu organisasi formal yang dimiliki seorang anggota organisasi kepada anggota yang lain untuk melakukan suatu kegiatan kerja sesuai dengan kontribusinya.

c. Disiplin adalah taat kepda hukum dan peraturan yang berlaku. Jadi, disiplin pegawai adalah kegiatan pegawai yang bersangkutan dalam menghormati perjanjian kerja dengan organisasi.

d. Inisiatif, yaitu berkaitan dengan daya pikir dan kreatifitas dalam membentuk ide merencanakan sesuatu yang berkaitan dengan tujuan organisasi.

Wirawan (2009) $)^{[23]}$ menjelaskan bahwa kinerja pegawai merupakan hasil sinergi dari sejumlah faktor. Faktor-faktor tersebut adalah faktor lingkungan internal organisasi, faktor lingkungan eksternal, dan faktor internal pegawai. Sedangkan faktor yang mempengaruhi kinerja menurut Mangkunegara (2005) ${ }^{[16]}$ adalah faktor kemampuan (ability) dan faktor motivasi (motivation). Faktor ability terdiri dari kemampuan potensi (IQ) dan kemampuan reality (knowledge + skill). Adapun faktor motivation terbentuk dari sikap (attitude) seorang pegawai dalam menghadapi situasi kerja.

Berhubungan dengan faktor yang mempengaruhi kinerja Mathis dan Jackson $(2006)^{[17]}$ menjelaskan bahwa terdapat tiga faktor yang berperan dalam kinerja pegawai, yaitu kemampuan individu untuk melakukan pekerjaan tersebut, tingkat usaha yang dicurahkan, dan dukangan organisasi.

Sedangkan indikator dalam pengıkuran kinerja menurut Peraturan Menteri Menteri Perindustrian Republik Indonesia Nomor 98/MIIND/PER/11/2015 $5^{[8]}$, Kinerja pegawai dapat diukur dari sasaran kerja pegawai dan produktifitas kerja pegawai. Adapun sasaran kerja pegawai meliputi kuantitas, kualitas, dan waktu. Sedangkan produktifitas kerja pegawai meliputi orientasi pelayanan, integritas, komitmen, disiplin, kerjasama, dan kepemimpinan.

a. Kuantitas, merupakan ukuran jumlah atau banyaknya hasil kerja yang dicapai oleh pegawai.

b. Kualitas, merupakan ukuran mutu setiap hasil kerja yang dicapai oleh pegawai.

c. Waktu, merupakan ukuran lamanya proses setiap hasil kerja yang dicapai oleh seorang pegawai.

d. Orientasi pelayanan, merupakan sikap dan perilaku kerja pegawai dalam memberikan pelayanan kepada yang dilayani antara lain meliputi masyarakat, atasan, rekan sekerja, unit kerja terkait, dan/atau instansi lain.

e. Integritas, merupakan kemampuan seorang pegawai untuk bertindak sesuai dengan nilai, norma dan etika dalam organisasi.

f. Komitmen, merupakan kemauan dan kemampuan seorang pegawai untuk dapat menyeimbangkan antara sikap dan tindakan untuk mewujudkan tujuan organisasi dengan mengutamakan kepentingan dinas daripada kepentingan sendiri, seseorang, dan/atau golongan. 
g. Disiplin, merupakan kesanggupan seorang pegawai untuk menaati kewajiban dan menghindari larangan yang ditentukan dalam peraturan perundang-undangan atau peraturan kedinasan yang apabila tidak ditaati atau dilanggar dijatuhi sanksi.

h. Kerja sama, merupakan kemauan dan kemampuan seorang pegawai untuk bekerja sama dengan rekan sekerja, atasan, bawahan baik dalam unit kerjanya maupun instansi lain dalam menyelesaikan suatu tugas dan tanggung jawab yang diembannya.

\section{Pengertian Motivasi Kerja}

Motivasi berasal dari kata motif (motive), yang berarti dorongan. Dengan demikian motivasi berarti suatu kondisi yang mendorong atau menjadi sebab seseorang melakukan suatu perbuatan/kegiatan, yang berlangsung secara sadar. Motivasi menurut Siswanto (2010) ${ }^{[22]}$ diartikan sebagai keadaan kejiwaan dan sikap, mental manusia yang memberikan energi, mendorong kegiatan (moves) dan mengarah atau menyalurkan perilaku ke arah mencapai kebutuhai yang memberi kepuasan atau mengurangi ketidakseimbangan.

Motivasi menurut Bangun (2012) ${ }^{[10]}$, motivasi didefinisikan sebagai suatu tindakan untuk mempengaruhi orang lain agar berperilaku (to behave) secara teratur. Motivasi merupakan tugas bagi pimpinan untuk mempengaruhi pegawai dalam suatu instansi kerja.

Dalam konteks pekerjaan, motivasi merupakan salah satu faktor penting dalam mendorong seorang pegawai untuk bekerja. Motivasi adalah kesediaan individu untuk mengeluarkan upaya yang tinggi untuk mencapai tujuan organisasi (Robbins, 2006) ${ }^{[21]}$. Ada tiga elemen kunci dalam motivasi yaitu upaya, tujuan organisasi dan kebutuhan. Upaya merupakan ukuran intensitas. Bila seseorang termotivasi maka ia akan berupaya sekuat tenaga untuk mencapai tujuan, namun belum tentu upaya yang tinggi akan menghasilkan kinerja yang tinggi. Oleh karena itu, diperlukan intensitas dan kualitas dari upaya tersebut serta difokuskan pada tujuan organisasi.

Kebutuhan adalah kondisi internal yang menimbulkan dorongan, dimana kebutuhan yang tidak terpuaskan akan menimbulkan tegangan yang merangsang dorongan dari dalam diri individu. Dorongan ini menimbulkan perilaku pencarian untuk menemukan tujuan, tertentu. Apabila ternyata terjadi pemenuhan kebutuhan, naka akan terjadi pengurangan tegangan. Pada dasarnya, pegawai yang termotivasi berada dalam kondisi tegang dan berupaya mengurangi tingkat ketegangan dengan mengeluarkan upaya. Proses motivasi dalam pemenuhan kebutuhan dapat dilihat pada gambar 1.

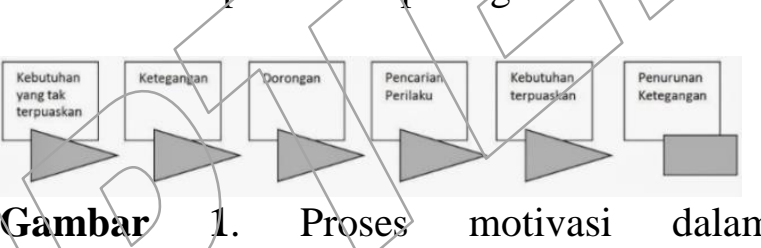
pemenuhan kebutuhan

Dari uraian-uraian di atas, dapat diatas yang disebut motivasi kerja adalah suatu kondisi yang menyebabkan pegawai melakukan pekerjaan untuk mencapai kebutuhan yang memberi kepuasan kepada pegawai dan berpengaruh terhadap pencapaian tujuan organisasi.

Dalam perkembangannya, motivasi dapat dipandang dalam empat pendekatan (Bangun, 2012) $)^{[10]}$, yaitu:

a. Traditional approach, lebih ditekankan pada pengawasan (controlling) dan pengarahan (directing). Pimpinan menemukan bahwa insentif berupa uang untuk memotivasi pegawai untuk melaksanakan pekerjaan yang berulang.

b. Human relation approach, dalam pendekatan ini ditemukan bahwa melaksanakan pekerjaan yang berulang dapat menyebabkan kebosanan yang dapat menurunkan motivasi, sedangkan kontak sosial membantu dalam menciptakan dan mempertahankan motivasi. 
c. Human resources approach, dalam pendekatan ini dinyatakan bahwa motivasi pegawai dipengaruhi oleh banyak faktor. Faktor yang mempengaruhi tidak hanya uang atau keinginan untuk mencapai kepuasan, tetapi juga kebutuhan untuk berprestasi dan memperoleh pekerjaan yang berarti.

d. Contemporer approach, dalam pendekatan ini motivasi dipengaruhi oleh tiga tipe motivasi, teori isi, teori proses, dan teori penguatan. Teori isi diantaranya adalah teori hierarki kebutuhan, teori ERG, dan teori dua faktor. Sedangkan teori proses diantaranya adalah teori keadilan, dan teori harapan. Adapun teori penguatan didukung oleh teori alat-alat penguatan.

Indikator motivasi kerja seorang pegawai menurut Rizka (2015) ${ }^{[3]}$ terdiri atas:

a. Mutu pekerjaan, merupakan peningkatan hasil pekerjaan baik secara kuantitas dan kualitas.

b. Pelaksanaan tugas, merupakan kemampuan yang harus dimiliki untuk melaksanakan tugas/ pekerjaan.

c. Inisiatif, merupakan keinginan/prakarsa dari pegawai untuk melaksanakan pekerjaan.

d. Hubungan kerja, merupakan hubungan kerja antara pimpinan dan pegawai.

e. Pengorbanan, merupakan pengakuan dan penghargaan yang diberikan kepada pegawai yang telah melaksanakan pekerjaan.

\section{Pengertian Gaya Kepernimpinan}

Lingkungan bisnis yang cepat berubah dan persaingan global yang semakin ketat membutuhkan pemimpin yang kreatif, inovatif serta memiliki kemampuan komunikasi yang baik untuk menjawab tantangan tersebut (Safuan, 2017) ${ }^{[6]}$. Selain itu diperlukan juga pemimpin yang visioner dan berani mengambil risiko dari tindakan yang diambil.

Setiap pemimpin pada dasarnya memiliki perilaku yang berbeda dalam memimpin para pegawainya, perilaku para pemimpin itu disebut dengan gaya kepemimpinan. Gaya kepemimpinan merupakan suatu cara pemimpin untuk mempengaruhi bawahannya yang dinyatakan dalam bentuk pola tingkah laku atau kepribadian. Seorang pemimpin merupakan seorang yang memiliki suatu program dan yang berperilaku secara bersama-sama dengan anggota-anggota organisasi dengan mempergunakan cara atau gaya tertentu, sehingga kepemimpinan mempunyai peranan sebagai kekuatan dinamik yang menđorong, memotivasi dan mengkoordinasikan perusahaan dalam mencapai tujuan yang telah ditetapkan. Gaya kepemimpinan didefinisikan oleh Hijri (2016) ${ }^{[24]}$ sebagai suatu cara pemimpin untuk mempengaruhi bawahannya yang dinyatakan dalam bentuk pola tingkah laku dan kepribadian.

Dari penjelasan diatas, gaya kepemimpinan yang dimaksud dalam penelitian ini adalah suatu proses untuk mengarahkan dan mempengaruhi pegawai agar dapat melaksanakan tugasnya untuk mencapai tujuan organisasi dalam bentuk pola tingkah laku dan kepribadian.

Menurut Hasibuan (2007) ${ }^{[12]}$ ada beberapa jenis kepemimpinan diantaranya adalah gaya kepemimpinan otoriter, demokratis dan kendali bebas.

Gaya kepemimpinan Otoriter adalah gaya pemimpin yang memusatkan segala keputusan dan kebijakan yang diambil dari dirinya sendiri secara penuh. Pada gaya kepemimpinan otokrasi ini, pemimpin mengendalikan semua aspek kegiatan. Pemimpin memberitahukan sasaran apa saja yang ingin dicapai dan cara untuk mencapai sasaran tersebut, baik itu sasaran utama maupun sasaran minornya. Pemimpin juga beperan sebagai pengawas terhadap semua aktifitas anggotanya dan pemberi jalan keluar bila anggota mengalami masalah. Dengan kata lain, anggota tidak perlu pusing memikirkan apapun. Anggota cukup melaksanakan apa yang diputuskan pimpinan. 
Kepemimpinan otokrasi cocok untuk anggota yang memiliki kompetensi rendah tapi komitmennya tinggi.

Gaya kepemimpinan demokratis adalah gaya pemimpin yang memberikan wewenang secara luas kepada para bawahan. Setiap ada permasalahan selalu mengikutsertakan bawahan sebagai suatu tim yang utuh. Dalam gaya kepemimpinan demokratis pemimpin memberikan banyak informasi tentang tugas serta tanggung jawab para bawahannya. Pada kepemimpinan demokrasi, anggota memiliki peranan yang lebih besar. Pada kepemimpinan ini seorang pemimpin hanya menunjukkan sasaran yang ingin dicapai saja, tentang cara untuk mencapai sasaran tersebut, anggota yang menentukan. Selain itu, anggota juga diberi keleluasaan untuk menyelesaikan masalah yang dihadapinya. Kepemimpinan demokrasi cocok untuk anggota yang memiliki kompetensi tinggi dengan komitmen yang bervariasi.

Gaya Kepemimpinan Kendali Bebas dimana pemimpin jenis ini hanya terlihat dalam kuantitas yang kecil dimana para bawahannya yang secara aktif menentukan tujuan dan penyelesaian masalah yang dihadapi. Gaya kepemimpinan kendali bebas merupakan model kepemimpinan yang paling dinamis. Pada gaya kepemimpinan ini seorang pemimpin hanya menunjukkan sasaran utama yang ingin dicapai saja. Tiap divisi atau seksi diberi kepercayaan penuh untuk menentukan sasaran minor, cara untuk mencapai sasaran, dan untuk menyelesaikan masalah yang dihadapinya sendiri-sendiri. Dengan demikian, pemimpin hanya berperan sebagai pemantau saja. Kepemimpinan kendali bebas cocok untuk anggota yang memiliki kompetensi dan komitmen yang tinggi.

Lebih lanjut indikator masing-masing gaya kepemimpinan dapat dijelaskan sebagaimana berikut:

a. Kepemimpinan Otoriter, dengan indikator:
1. Ancaman, pimpinan memberikan instruksi kerja dengan disertai sanksi apabila tidak dilaksanakan perintahnya.

2. Pengawasan ketat, pekerjaan yang diberikan diawasi dalam pelaksanaan dan penyelesaiannya.

3. Tertutup, pengambilan keputusan dan kebijaksanaan hanya ditetapkan sendiri oleh pimpinan, bawahan tidak diikutsertakan untuk memberikan saran, ide, dan pertimbangan dalam proses pengambilan keputusan.

\section{b. Kepemimpinan demokratis}

1. Komunikatif, pimpinan memberikan instruksi kerja dengan petunjuk pelaksanaan sesuai dengan peraturan perundang-undangan. 2. Konsultatif, dalam pelaksanaan pekerjaan membuka ruang untuk berkonsultasi dalam penyelesaian pekerjaan, dan bawahan didorong untuk mengarnbil keputusan terkait penyelesaian pekerjaan.

3. Terbuka, keputusan tetâp dilakukan pimpinan dengan mempertimbangkan saran atav ide yang diberikan bawahannya.

\section{c. Kepemimpinan kendali bebas}

1. Tuntutan Ketrampilan, pimpinan mengarggap bawahan dapat menyelesaikan pekerjaan dengan kemampuannya.

2. Kepercayaan, pimpinan menyerahkan tanggung jawab pelaksanaan pekerjaan sepenuhnya kepada bawahan.

3. Kebebasan, bawahan dapat mengambil keputusan terkait penyelesaian pekerjaan.

\section{METODE PENELITIAN}

Penelitian merupakan penelitian dengan studi literatur mengenai pengaruh gaya kepemimpinan terhadap motivasi kerja, pengaruh motivasi kerja terhadap kinerja pegawai, serta pengaruh gaya kepemimpinan terhadap kinerja pegawai secara langsung.

\section{HASIL PEMBAHASAN}




\section{Pengaruh gaya kepemimpinan terhadap motivasi kerja}

Menurut Kartono (2006) $)^{[15],}$ Gaya kepemimpinan adalah sifat, kebiasaan, temperamen, watak dan kepribadian yang membedakan seorang pemimpin dalam berinteraksi dengan orang lain. Gaya kepemimpinan seorang pemimpin dalam organisasi sangat penting dalam kemajuan organisasi untuk maju mundurnya suatu perusahaan tergantung dari gaya kepemimpinan seorang pemimpin baik dalam proses mempengaruhi, mengarahkan dan memberikan pengaruh yang penting agar tujuan perusahaan tercapai.

Gaya kepemimpinan yang baik adalah gaya kepemimpinan yang dapat memberikan motivasi kerja pada bawahannya. Ivancevich $(2001)^{[14]}$ mengatakan, seorang pemimpin harus menyatukan berbagai keahlian, pengalaman, kepribadian dan motivasi. Kinerja pegawai akan baik apabila pimpinan dapat memberi motivasi yang tepat dan pimpinan memiliki gaya kepemimpinan yang dapat diterima oleh seluruh pegawai dan mendukung terciptanya suasana kerja yang baik. Gaya kepemimpinan yang efektif, akan memberikan pengarahan yang baik pada bawahannya terhadap usaha-usaha semua pekerjaan dalam mencapai tujuan. Selanjutnya Riyadi (2011) ${ }^{[2]}$, Syafi'i (2015) ${ }^{5]}$, Hijri (2016) ${ }^{[24]}$ dalam penelitiannya meyatakan bahwa variabel gaya kepemimpinan berpengaruh terhadap variabel motivasi keria.

Kinerja pegawai akan baik apabila pimpinan dapat memberi motivasi yang tepat dan pimpinan memiliki gaya kepemimpinan yang dapat diterima oleh seluruh pegawai dan mendukung terciptanya suasana kerja yang baik. Gaya kepernimpinan yang efektif, akan memberikan pengarahan yang baik pada bawahannya terhadap usaha-usaha semua pekerjaan dalam mencapai tujuan

\section{Pengaruh motivasi kerja terhadap kinerja pegawai}

Menurut Henry Simamora (Mangkunegara, 2005) ${ }^{[16]}$ menyatakan bahwa terdapat hubungan antara motivasi kerja terhadap kinerja. Faktor yang mempengaruhi kinerja diantaranya yaitu motivasi kerja. Hal ini dilihat dari pernyataan Henry Simamora mengenai faktor-faktor yang mempengaruhi kinerja, diantaranya faktor psikologis, dalam faktor ini terdapat variabel motivasi kerja terhadap pekerjaannya sendiri. Berdasarkan dari pernyataan diatas bahwa terdapat hubungan antara motivasi kerja terhadap kinerja. Dimana kinerja merupakan kualitas dan kuantitas dari suatu hasil kerja (output) individu maupun kelompok dalam suatu aktivitas tertentu yang diakibatkan oleh kemampuan alaini atau kemampuan yang diperoleh dari proses belajar serta keinginan beprestasi.

Lebih lanjut, Taghipour $(2013)^{[7]}$ menyatakan bahwa motivasi kerja berhubungan dengan kinerja pegawai, dimana saat pegawai termotivasi untuk masuk ke tempat kerja, naka kinerja akan meningkat. Selain itu hubungan kerja antara pimpinan sebagai motivator dapat meningkatkan kinerja pegavai dalam organisasi.

Pee $(2016)^{[1]}$ dalam penelitiannya meyebutkan bahwa peningkatan motivasi sangat dipengaruhi oleh tingkat pemahaman pegawai mengenai ruang lingkup pekerjaan yang dilakukan oleh pegawai.

Sedangkan penelitian yang dilakukan oleh beberapa peneliti tentang motivasi kerja dan kinerja pegawai saling mempengaruhi. Penelitian yang dilakukan oleh Riyadi $(2011)^{[2]}$, Taghipour $(2013)^{[7]}$, Musliyadi $(2015)^{[25]}$, dan Hijri $(2016)^{[24]}$, meyatakan bahwa variabel kinerja dipengaruhi oleh variabel motivasi kerja.

Dari berbagai penjelasan diatas, dapat dilihat bahwa terdapat pengaruh antara motivasi 
kerja terhadap kinerja pegawai, dimana peningkatan motivasi kerja dari pegawai akan berpengaruh terhadap peningkatan kinerja pegawai.

\section{Pengaruh gaya kepemimpinan terhadap kinerja pegawai}

Kemajuan organisasi sangat dipengaruhi oleh kinerja pegawainya. Setiap organisasi akan terus berusaha untuk meningkatkan kinerja pegawainya agar dapat mencapai hasil kerja yang baik dan memuaskan. Untuk mencapainya memerlukan banyak usaha yang harus dilakukan baik oleh pimpinan dengan gaya kepemimpinannya maupun para pegawai dengan kinerja yang dihasilkan. Setiap pemimpin mempunyai kewenangan dan tanggung jawab dalam menentukan seluruh kegiatan diperusahaan, setiap manajer atau pimpinan organisasi tersebut memiliki tanggung jawab yang besar dalam seluruh proses yang biasanya termasuk dalam manajemen sumber daya manusia yang berkaitan dengan para pegawai yang berada dalam kewenangannya, sehingga dibutuhkan kemampuan dan ketrampilan yang tinggi untuk memimpin pegawainya dalam perusahaan.

Menurut Habsari (2008) ${ }^{[13]}$ dalam bukunya Terobosan Kepemimpinan, kepemimpinan yang efektif memiliki ciri-ciri sebagai berikut, memperhitungkan minat sampai hasil akhir, memahami bahwa hasil adalah selalu penilaian terakhir, memiliki semangat menyelesaikan masalah, lebih demokratis dari pada autority, memberikan kesempatan untuk mencapai potensi setiap orang, memiliki etika dan moral yang tinggi, mengambil tanggung jawab terhadap hasil tim.

Menurut penelitian yang dilakukan Somech $(2006)^{[4]}$, Gaya kepemimpinan berpengaruh terhadap kinerja pegawai. Dalam konteks ini, motivasi menjelaskan suatu aktifitas manajemen atau sesuatu yang dilakukan seorang manajer untuk membujuk atau mempengaruhi bawahannya untuk bertindak secara organisator dengan cara tertentu agar dapat menghasilkan kinerja yang efektif.

Selanjutnya penelitian yang dilakukan oleh Riyadi (2011) $)^{[2]}$, Sulaiman (2013) ${ }^{[26]}$, Syafi'i $(2015)^{[5]}$, Yakub (2016) $)^{[27]}$, dan Hijri $(2016)^{[24]}$ meyatakan bahwa variabel gaya kepemimpinan berpengaruh terhadap variabel kinerja pegawai.

\section{KESIMPULAN}

Gaya kepemimpinan merupakan gaya yang digunakan oleh pemimpin untuk dapat mengelola sumber daya yang ada dalam organisasi, termasuk didalamnya sumber daya manusia. Peran pemimpin sangatlah penting dalam melakukan kegiatan motivasi kepada sumber daya manusia yang menjadi pegawainya untuk dapat bekerja lebih baik. Dengan meningkatnya motivasi kerja para pegawai diharapkan dapat meningkatkan kinerja pegawai yang ada dalam suatu organisasi, séhingga tujuan organisasi dapat tercapai dengan baik.

Dari pembahasan diatas, seorang pemimpin harus dapat memahami tipe gaya kepernimpinan, dan menyesuaikan gaya kepemimapinannya dengan kondisi organisasi yang dipimpinnya, sehingga gaya kepemimpinan yang digunakan dapat meningkatkan motivasi kerja pegawai, menirigkatnya kinerja pegawai, dan tercapainya tujuan organisasi. Dengan gaya kepemimpinan yang sesuai dengan organisasi akan berpengaruh terhadap tingkat motivasi kerja pegawai, sehingga secara signifikan dapat meningkatkan kinerja pegawai dalam suatu organisasi.

\section{DAFTAR PUSTAKA}

[1] Pee, L. G. Dan Lee, J. (2015). Intrinsically motivating employees' online knowledge sharing: Understanding the effects of job 
design. International Journal of Information Management, 35, 2015, 679-690.

[2] Riyadi, S. (2011). Pengaruh kompensasi finansial, gaya kepemimpinan dan motivasi kerja terhadap kinerja karyawan pada perusahaan manufaktur di jawa timur. Jurnal Manajemen dan Kewirausahaan, Vol.13, No.1, 2011, 40-45.

[3] Rizka, N. Yusuf, R. Majid, M.S.A. (2015). Pengaruh struktur organisasi dan analisis jabatan terhadap motivasi kerja dan dampaknya pada kinerja sekretariat Majelis Permusyawaran Ulama (MPU) Aceh. Jurnal Manajemen Pascasarjana Universitas Syiah Kuala, ISSN 2302-0199, pp 1-9.

[4] Somech, A. (2006). The effect of leadership style on performance improvement on a manufacturing task. Journal of Business, Vol. 72

[5] Syafi'i, L. I. Thoyib, A. Nimran, U. Djumahir. (2015). The Role of Corporate Culture and Employee Motivation as a Mediating Variable of Leadership Style related with the Employee Performance (Studies in Perum Perhutani). Procedia-Social and Behavioral Sciences, 211, 2015, 1142-1147.

[6] Safuan. (2017). Pengembangan Sumber Daya Manusia Berjiwa Kepemimpinan Wirausaha Dalam Menghadapi Tantangan Global. Jurnal Manajemen Industri dan Logistik, 2017, ISSN 2598-5795, p89-96.

[7] Taghipour, A. dan Dejban, R. (2013). Job Performance: Mediate Mechanism of Work Motivation. Procedic-Social Behavioral Sciences, 84, 2013, 16011605.

[8] Peraturan Menteri-Perindustrian Nomor 98 /M-IND/PER/11/2015 tentang Mekanisme Pemberian Tunjangan Kinerja Bagi Pegawai di
Lingkungan

Kementerian Perindustrian.

[9] Amstrong, M. (1999). Manajemen Sumber Daya Manusia. Terjemahan Sofyan dan Haryanto. Jakarta: Elex Media Komputindo.

[10] Bangun, W. (2012). Manajemen Sumber Daya Manusia. Jakarta: Gelora Penerbit Erlangga.

[11] Dessler, G. (2007). Manajemen Personalia. Edisi Ketiga. Jakarta: Erlangga.

[12] Hasibuan, M. S. P. (2007). Manajemen SDM. Edisi Revisi. Jakarta: Bumi Aksara.

[13] Habsari, A. R. (2008). Terobosan Kepemim pinan. Yogyakarta: Med Press.

[14] Ivancevich. (2008). Perilaku dan Manajemen Organisasi. Jakarta : Erlangga

[15] Kartono, K. (2006). Pemimpin dan Kepemim-pinan. Jakarta: Rajawali.

[16] Mangkunegara, A. P. (2005). Manajemen Sumber Daya Manusia Perusahaan. Bandung: Remaja Rosdakarya.

[17] Mathis, R. L. \& J. H. Jackson. (2006). Human Resource Management: Manajemen Sumber Daya Manusia. Terjemahan Dian Angelia. Jakarta: Salemba Empat.

[18] Nurlaila. (2010). Manajemen Sumber Daya Manusia I. Ternate: LepKhair.

[19] Prawirosentono, S. (1999). Kebijakan Kinerja Karyawan. Yogyakarta: BPFE.

[20] Riyai, V. (2009). Manajemen Sumber Daya Manusia untuk Perasahaan. Jakarta: Raja Grafindo Persada.

[21] Robbins, S. P. (2006). Perilaku Organisasi. Jakarta: Indeks Kelompok Gramedia.

[22] Siswanto, H. B. (2010), Pengantar Manajemen. Bandung: Bumi Aksara.

[23] Wirawan. 2009. Evaluasi Kinerja Sumber Daya Manusia : Teori, Aplikasi dan Penelitian. Jakarta : Salemba Empat.

[24.] Hijri, S. (2016), Pengaruh gaya kepemimpinan dan motivasi terhadap motivasi kerja serta dampaknya pada kinerja pegawai Badan Pelaksana Penyuluhan Pertanian, Perikanan dan Kehutanan (BP4K) Kabupaten Aceh Barat. Tesis, Fakultas Ekonomi dan Bisnis: Universitas Syiah Kuala. 
[25] Musliyadi. (2015). Pengaruh insentif, moti-vasi, lingkungan kerja dan budaya organisasi terhadap kinerja pegawai serta dampaknya pada kinerja badan layanan umum daerah rumah sakit umum Thk. Chik Ditiro Sigli Aceh. Tesis, Fakultas Ekonomi dan Bisnis: Universitas Syiah Kuala.

[26] Sulaiman. (2013). Pengaruh gaya kepemim-pinan dan gaya komunikasi terhadap kinerja pegawai serta dampaknya pada kinerja Sekretariat Daerah Kabupaten Pidie Jaya. Tesis, Fakultas Ekonomi dan Bisnis: Universitas Syiah Kuala.

[27] Yakub, S. (2016). Pengaruh Gaya Kepemim-pinan, Struktur Organisasi dan Kompetensi Terhadap Kinerja Pegawai serta dampaknya pada Efektivitas Organisasi Kantor Pos Banda Aceh. Tesis, Fakultas Ekonomi dan Bisnis: Universitas Syiah Kuala 